\title{
Why adopt ISO 9001 certification in hospitals? A case study of external triggers and sensemaking in an emergency department in Norway
}

Dag Tomas Sagen Johannesen ${ }^{1,2^{*}}$ (1) and Siri Wiig ${ }^{3}$

\begin{abstract}
Background: Certification and accreditation are widely used to achieve quality and safety in health care but are also questioned regarding their assumed effects. This is a challenge for policymakers and managers, since adoption of these regimes can have a circumstantial impact upon organizations. This study's aim was to explore how external conditions catalyzed and triggered organizational change and internal sensemaking processes as part of an ISO 9001 certification process.

Methods: The study applied an explanatory single-case design, using a narrative approach, to retrospectively follow a sensemaking process in an emergency department in a Norwegian hospital undergoing ISO 9001 certification. The certification process was a pilot initiated by a Regional Health Authority, which ran from autumn 2008 until spring 2012. Nine semi-structured, qualitative interviews were conducted, and documents in the form of minutes and reports were collected. The data was analyzed according to an organized sensemaking framework.

Results: The adoption of the ISO 9001 certification did not follow a comprehensive decision-making process. Our study shows two external situational triggers that initiated adoption. First, a countrywide supervision conducted by the Norwegian Board of Health Supervision concluded that inadequate management and leadership negatively affected the day-to-day running of Norwegian emergency departments. This external disruption visualized longstanding organizational challenges that threatened the managers' shared identity. A search for meaning became prominent. Second, an occasional, externally initiated certification project was a plausible solution that would lead to an immediate action that would reduce uncertainty. Institutional requirements and concepts in the international ISO 9001 standard and in the national health regulations were unfamiliar and ambiguous for the project group involved in the certification. These issues became the institutional external triggers for intra-organizational sensemaking processes that made ISO certification possible. External assessments were acknowledged as useful for making improvements.
\end{abstract}

Conclusions: By combining institutional theory with sensemaking theory, this case study contributes to a better understanding of how external pressure meets micro-level change processes. These understandings are important because environments give rise to adoption of different management tools, such as certification, but organizations adopting new management tools seldom abandon others. This can lead to even more complex health care.

Keywords: Certification, Accreditation, ISO, Quality improvement, Sensemaking, Organizing, Change, Institutional theory, Narrative analysis

\footnotetext{
* Correspondence: dag.t.johannesen@uia.no

${ }^{1}$ Department of Media, Culture and Social Sciences, University of Stavanger,

4036 Stavanger, Norway

${ }^{2}$ Department of Health and Nursing Science, University of Agder, 4604

Kristiansand, Norway

Full list of author information is available at the end of the article
}

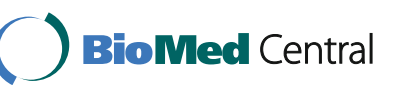

(c) The Author(s). 2017 Open Access This article is distributed under the terms of the Creative Commons Attribution 4.0 International License (http://creativecommons.org/licenses/by/4.0/), which permits unrestricted use, distribution, and reproduction in any medium, provided you give appropriate credit to the original author(s) and the source, provide a link to the Creative Commons license, and indicate if changes were made. The Creative Commons Public Domain Dedication waiver (http://creativecommons.org/publicdomain/zero/1.0/) applies to the data made available in this article, unless otherwise stated. 


\section{Background}

Accreditation and certification programs in health care are used internationally to ensure, regulate and drive quality improvement and safety initiatives. Starting as a professional self-regulatory standardization and control initiative in the early years of the twenty-first century, the number of programs globally has grown tremendously in the last 25 years. In Norway such programs have no clear history other than some small ad hoc initiatives. At a national level, nationwide certification and accreditation programs have been debated $[1,2]$ and were recommended by the Government in 2015 [3]. Claims about a limited evidence base and rigorous study designs of the effects upon recognized quality measures have been put forward in several international publications, especially in relation to how many resources are allocated to accreditation and certification systems internationally [4-6]. Recently, two updated systematic reviews about the effects of certification and accreditation [5] or external inspections [7] upon process or clinical outcomes only found respectively one and two studies that met their inclusion criteria. The authors found no strong evidence to conclude about the effectiveness of certification or accreditation. Earlier reviews, with broader inclusion criteria report in general inconsistent findings on the relationships between certification and accreditation programs and clinical performance and outcomes, a positive trend about the programs ability to stimulate improvement work and promote organizational and cultural change and change in professional practice concerned with quality of care, and contrasting views among professionals towards accreditation [8-10]. Studies of 89 European hospitals indicate that accreditation and International Organization for Standardization (ISO) 9001 certification are positively associated with some quality and safety structures and hospital outputs such as hospital management, clinical practice, safety, patient-centeredness and cross-border patient-centeredness. These studies demonstrated that accreditation has slightly more impact than ISO certification, but either system is better than no external assessment $[11,12]$. The recent EU project DUQUE with data from 73 European hospitals studied the relationship between ISO 9000 certification, healthcare accreditation, and quality management. The researchers concluded that accreditation and certification were positively associated with clinical leadership, systems for patient safety, and clinical review, but not with clinical practice [13]. In a Danish nationwide population-based study the researchers reported a lower 30-day mortality risk for admissions at fully accredited hospitals compared to admissions at partially accredited hospitals [14]. Using an interrupted times series analysis following one hospital in Abu Dhabi over 3 years, the researchers showed that the positive impact of healthcare accreditation on hospital quality measures to some degree was maintained during the 3 years accreditation cycle, but concluded that more focus on continuous improvement methods to sustain the positive impact form accreditation was needed, for instance, frequently self-assessment or unannounced external reviews [15]. The use of unannounced external reviews was recently studied in a nationwide clusterrandomized controlled trial [16]. No difference between announced and unannounced surveys in detecting non-compliance with accreditation standards in hospitals was found.

The uncertain relationship between adaption of different accreditation or certification programs and quality and safety objectives poses a challenge for policymakers and managers. Despite these challenges, hospital certification and accreditation are widely used and differ extensively in their purpose and organization [10, 17]. Certification and accreditation can therefore be considered as a legitimate and institutionalized means of regulation of quality and safety in hospitals, and in complex organizations they reflect contemporary tendencies of means-ends decoupling [18]. In means-ends decoupling, we see that the adoption of new policies or formal structures has a real impact upon change of organizational activities and cultures, but there is limited evidence linking these changes to organizational effectiveness and outcomes (see Fig. 1).

Figure 1 presents the questions about why complex organizations allocate resources to practices that have a scarce or diffuse known relationship to organizational objectives. In hospitals, such objectives are most often linked to better outcomes of patient care. This case study takes these questions into a hospital context in Norway, and investigates why and how an emergency department (ED) adopted and was certified in the ISO 9001:2008 Quality management systems - Requirements standard.

\section{ISO 9001 certification-what is it?}

ISO 9001 certification can be seen as an external conformity assessment or control mechanism to assure and regulate quality and safety in health care. It is often compared to or described interchangeably within the "family" of external assessment strategies for health care organizations, and especially accreditation [19, 20]. The common purpose of these external assessment programs is to provide information and evidence that the organizational system and performance conform to a specific standard, and both certification and accreditation programs award the assessed organization with a certificate on successful conformity. Certification bodies and auditors should strive to build confidence and trust through a practice rooted in impartiality, competent assessments, and decisions based on objective evidence [21]. The ISO 9001 standard does not prescribe performance requirements. 


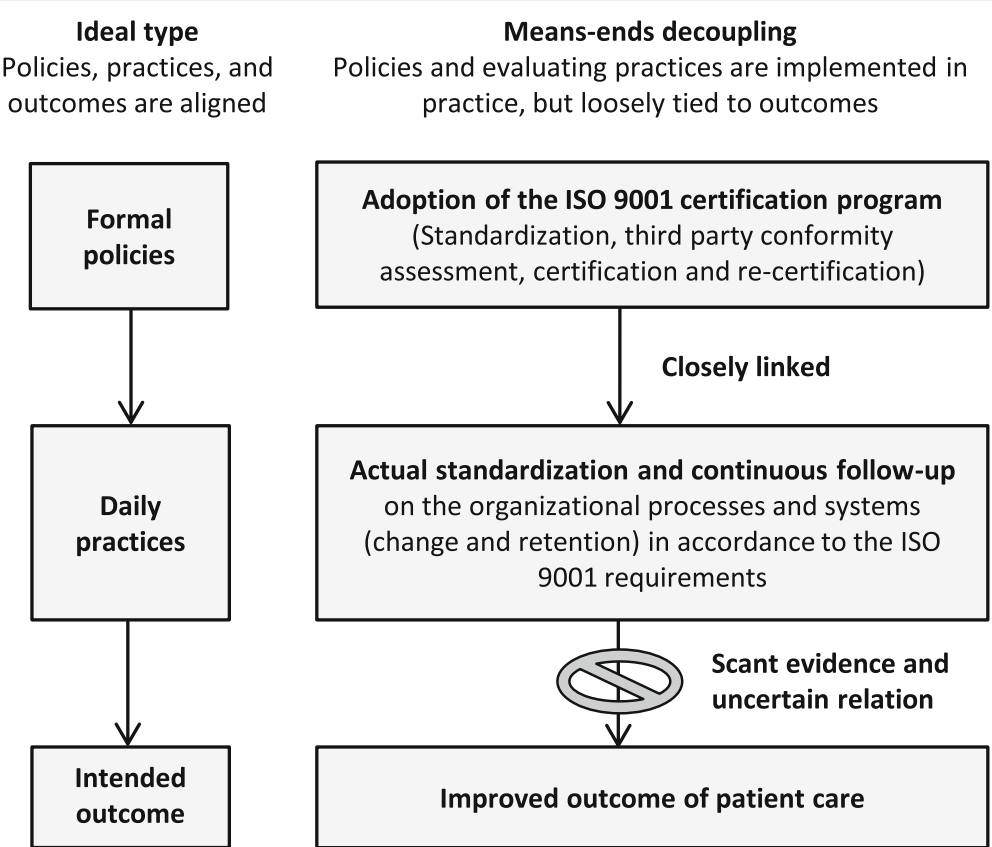

Fig. 1 Possible means-ends decoupling for ISO 9001 certification in hospitals. The figure is adopted and modified from Bromley \& Powell [18]

Rather, it proposes generic requirements for structures and systems that enable organizations to formalize production or service processes into a series of procedures, and to continuously monitor, document and improve its efficiency upon customer (patients) requirements and legal regulations [22, 23]. An audit program has a 3-year audit cycle: the initial certification process, two shorter "surveillance audits" over the next 2 years, and then re-certification in the third year.

\section{Aim and research question}

The aim of this case study is to explore external conditions that may catalyze and trigger organizational change [24-27], and internal sensemaking processes in the local ED management [24] that led to the continuity and change in favor of ISO 9001 certification. The following research questions guided the study:

- How do external environments contribute to an adoption of ISO 9001 certification in an emergency department?

- How does the local management make sense of the certification process?

This paper reports on the sensemaking processes in an emergency department in a Norwegian hospital undergoing ISO certification. By combining institutional theory with sensemaking theory, the paper contributes to a better understanding of how external pressure meets a local conceptualization of quality management processes in ISO certification.

\section{Theoretical approach}

The rise in certification and accreditation practices in healthcare [17] reflects the shifting mode in regulation (often a reduction in "hard laws" and directives), spread and diffusion of modern management tools, and demands for accountability and transparency in our contemporary society. In this case study, we treat the interplay between the enforced internal control regulations and voluntary ISO certification from the perspective of re-regulation [28] or decentered or plural regulation [29]. Typical of such regulation is the transformation into modes of governance ${ }^{1}$; with or without governments, often transnational in structure, and represented by non-binding "soft" rules and regulations. Such soft regulations are often diffuse and lead organizations to search for other means and control mechanism [28, 30].

To study the interplay between mandatory regulatory demands in healthcare and the voluntary adoption of ISO certification in a Norwegian hospital context, we draw on the contributions of institutional and sensemaking theory.

\section{Institutional trigger}

The present study emphasizes how macro institutional elements shape, trigger, or become situated by organizations and individuals, but with less influence over the continuing intra-organizational sensemaking processes [25, 27, 31]. People act and then use institutional structures to give meaning to their actions. This perspective breaks with more traditional perspectives where institutional environments 
place cognitive constraints upon organizations and intraorganizational processes by preclusion of other alternatives. According to Weber and Glynn [25], there are three mechanisms in addition to traditional cognitive constrains whereby institutional context affects sensemaking: priming, editing and triggering. Institutional contexts, in their view, refer to both the external institutional environment and institutionalized structures or scripts within organizations. People acting in situations extract cues to activate sensemaking processes. In this case study, we follow the triggering mechanisms [25] which relate to how contradictions, ambiguities, and gaps inherent in stable institutional structures create puzzles that require people to search for meaning. For example, the Norwegian healthcare regulation and the international ISO 9001 certification system represent different institutional structures that when adopted are supposed to constrain action. They also carry different legitimacy mechanisms that when adopted in different organizational contexts have the potential to be ambiguous, diffuse, or incomprehensible.

\section{Sensemaking, turbulence, and change}

The sensemaking perspective [24, 31, 32] helps to see the micro processes that enfold when managers adopt popular quality and safety programs, such as total quality management, six sigma, and LEAN management. Adoption processes do not follow rational, instrumental decision-making processes, rather they are filled with constantly changing sensemaking processes in order to give meaning to changing situations and outcomes $[31,33]$. Sensemaking is most evident when the world is perceived to be different from its expected state or when there are surprises [31]. Such diversity is described as triggers or a discrepant set of "cues" [24] enacted by individuals. Cues can be small bits of information, events or simple familiar structures, and people turn to earlier scripts, schemes, or frames to ascribe meaning to cues and decipher the situation. In other words, people are guided by institutional constraints, organizational premises, plans, expectations, acceptable justification, and traditions inherited from predecessors [31]. Weick [24] explains the sensemaking mechanisms that foster these organizational processes as thoughts, feelings, and intentions, the "intrasubjective meanings", being merged into "intersubjective meanings" through conversations. In times of stability, individuals draw on common scripts and frames to make sense of situations. But, in times of turbulence and change, these "old" scripts no longer work. A gap needs to be filled and an intersubjective or collective sensemaking process again becomes prominent. People look for reasons to continue or resume their work. In the search for reasons, sensemaking is about the interplay of action and interpretation rather than the influence of evaluation on choice [31]. It is not about accuracy and truth, but about plausibility. People continually redraft their stories in their search for meaning, so the stories become more comprehensive and resilient to criticism, and richer in data. Important in our case study was how a local project group constructed a story that we regard as collective shared meanings. Shared meanings is a core theme for both crisis sensemaking and change sensemaking [26].

\section{Methods}

In this section we will describe the regulatory context of Norwegian hospitals. Then we continue with design and data collection and present our analytical framework.

\section{Context and internal control regulation in Norway}

The Ministry of Health and Care Services has the overall responsibility for the specialized health care services in Norway. Public hospitals are owned by the Government and organized in four Regional Health Authorities (RHA).

The regulation of quality and safety for health service providers in Norway is based on a functional legislation, outlined as enforced self-regulation [34], where different regulatory requirements are based on an internal control system [35]. Hospitals have in this perspective a great deal of latitude to make decisions and set priorities about their organization and services [36].

All hospitals, their service and health personnel, are subject to supervision by the Norwegian Board of Health Supervision (NBHS), through the 18 Offices of the County Governors. The main supervision of hospitals is performed as system audits, whose aim is to ensure and control whether health services are complying with national acts and regulations. In practice it involves auditing the health service's internal control system.

In 2005, a RHA voluntarily adopted the ISO 9001 as a guide for all its hospitals, in order to operationalize the internal control system requirements [37]. It was argued that an identified lack of follow-up on the internal control system could be connected with difficult conceptualizations, vague demands, and uncertainties about overall quality management systems and its advantages [38].

\section{Design}

The present study is designed as an explanatory singlecase study [39]. For explanation building, we used a narrative approach [40-45] and storytelling [46] to retrospectively follow sensemaking during the local ISO 9001 certification process of an ED in a hospital trust in Norway. The process ran from autumn 2008 until spring 2012.

An overall story or narrative was produced during the research process. It illustrates how those involved in a local project group collectively made sense of the 
practices and experiences that unfolded during the certification process. The stories and meanings that the informants provide about past experiences can in itself be seen as a sensemaking process, as the nature of sensemaking builds upon frames that continuously change as the informant act and acquires experience [24]. The narrative can as such be seen as a co-construction between the informants and the author (the researcher), in addition to stories from documents (artefacts), and are constructs through which events are made sense of rather than just representations of these processes [40].

\section{Sample and data collection}

The case study relies on data produced from qualitative interviews and documents $[39,47]$. An initial exploratory interview was conducted in June 2011. Then documents and informants were selected for further study. Data derived from documents took the form of minutes of meetings and reports that were made available by informants and official websites (Table 1). The main data collection was performed during spring and autumn 2012.

Twelve informants were firstly purposefully selected. All were managers and key personnel in the ED, head of clinical and service departments, key personnel in the certification process, and the project management in the Regional Health Authority. After conducting eight interviews (Table 2), a distinct picture of the key local project management for the certification process could be drawn. The eight interviews revealed a distinct local organizing and sensemaking process, especially that of the local project management (and the local ED management, since managers were represented in the project management).

Semi-structured interviews were conducted in June and August 2012, according to an interview guide and centered upon three themes: (1) the subjects' role, the organization, and aspects concerning quality and safety work; (2) the certification process and its results; and (3) how ISO 9001 standard and certification was understood in relation to formal quality and safety regulations and management tools. Open questions were generally used, often followed by either preplanned or ad hoc probing questions, in order to help subjects to recall and tell more detailed stories about the ISO certification process and their experiences.

\section{Analytical framework and process}

Organized sensemaking is primarily a process theory. When conceptualized organized sensemaking can be treated as a sequence of "ecological change-enactment-selection [and]-retention [31]". Ecological changes in this context are treated as both intra- and inter-organizational environments. In the organizing process of enactment, people are shaped by environments and sense anomalies that are "...triggered by discrepancies and equivocality in ongoing projects, [and] begin to change the flux of circumstances into the orderliness of situations" [31]. Selection is a process of narrative reduction where possible meanings are reduced and generate a tentative and plausible story. In retention the plausible story is connected to past experience and fit with identity, and such makes a new script or cognitive frame that feeds back to the prior processes. In this case study we have applied the following analytical categories, modified, and adopted from Steyer et al. [48], that aims to emphasize the key elements in organized sensemaking processes [24, 31, 49] (See Fig. 2):

Frame (retention): Involves cognitive frames (retained plausible stories, such as acquired from work, training or life experiences) and formal frames (e.g., categories, plans, procedures, organizational structures, and artefacts). Frames are sources of guidance for interpretation and action.

Cue: Information or event extracted from the environment by actors. People ascribe meaning to cues by relating them to frames.

Table 1 Data sources—documents

\begin{tabular}{|c|c|c|c|}
\hline Data source & Type of document & Year & Document title \\
\hline $\begin{array}{l}\text { Norwegian Board of Health } \\
\text { Supervision - Office of the } \\
\text { County Governor }\end{array}$ & Report & 2007 & $\begin{array}{l}\text { Report from supervision of adequacy and quality in the } \\
\text { emergency department in somatic specialist health service } \\
\text { in xxx hospital }\end{array}$ \\
\hline $\begin{array}{l}\text { Norwegian Board of Health } \\
\text { Supervision }\end{array}$ & Report & 2008 & $\begin{array}{l}\text { "While we are waiting...."-do patients receive adequate } \\
\text { treatment in accident and emergency units? }\end{array}$ \\
\hline $\begin{array}{l}\text { Regional Health Authority and } \\
\text { Norwegian Accreditation }\end{array}$ & Project description & 2008 & $\begin{array}{l}\text { Accreditation in emergency departments "... for good and } \\
\text { equal health services" }\end{array}$ \\
\hline $\begin{array}{l}\text { Norwegian Accreditation Sector } \\
\text { committee P14 Emergency } \\
\text { departments }\end{array}$ & Report & 2010 & $\begin{array}{l}\text { Report from the Norwegian Accreditation Sector Committee } \\
\text { P-14 Emergency Departments }\end{array}$ \\
\hline Norwegian Accreditation & $\begin{array}{l}\text { Guidelines (including special or } \\
\text { extended scope of requirements) }\end{array}$ & 2010 & $\begin{array}{l}\text { NA Doc. } 59 \text { Guidelines of ISO 9001:2008 for Emergency } \\
\text { Departments }\end{array}$ \\
\hline Emergency Department & Minute & 2010 & $\begin{array}{l}\text { Evaluation meeting about ISO certification of the emergency } \\
\text { department 08.02.10. }\end{array}$ \\
\hline
\end{tabular}


Table 2 Data sources-interview subject profiles

\begin{tabular}{|c|c|c|}
\hline Formal position & Role in the certification project & Formal education \\
\hline Head of Department, ED & $\begin{array}{l}\text { Leader of the local project group, and the } \\
\text { local pilot projects (EDs) representative in the } \\
\text { overall regional project organization }\end{array}$ & $\begin{array}{l}\text { Intensive care nurse, Master of } \\
\text { Management }\end{array}$ \\
\hline Head of Section, ED & Member of the local project group & $\begin{array}{l}\text { Intensive care nurse, Master of } \\
\text { Management }\end{array}$ \\
\hline Head of Unit-1, ED & Member of the local project group & $\begin{array}{l}\text { Nurse, Ongoing (2012) Master of } \\
\text { Management }\end{array}$ \\
\hline Head of Unit-2, ED & Member of the local project group & Emergency care nurse \\
\hline $\begin{array}{l}\text { Quality Advisor, Quality and } \\
\text { research department }\end{array}$ & Member of the local project group & $\begin{array}{l}\text { Nurse, Master of Management, } \\
\text { Quality studies }\end{array}$ \\
\hline $\begin{array}{l}\text { Project Leader, Regional Health } \\
\text { Authority }\end{array}$ & $\begin{array}{l}\text { Project leader in the overall regional project } \\
\text { and focal point for the local pilot project in the } \\
\text { emergency department }\end{array}$ & $\begin{array}{l}\text { Nurse, Master of Health } \\
\text { Administration, Quality studies }\end{array}$ \\
\hline $\begin{array}{l}\text { Head of quality and research } \\
\text { department }\end{array}$ & $\begin{array}{l}\text { Allocated personnel to the local certification } \\
\text { project group }\end{array}$ & Unknown \\
\hline $\begin{array}{l}\text { Head of doctors, Department of } \\
\text { internal medicine }\end{array}$ & $\begin{array}{l}\text { Managed doctors working in the Department } \\
\text { of internal medicine }\end{array}$ & Nurse \\
\hline
\end{tabular}

Discrepancy: Equivocality and discrepancies between cues, and between cues and frames. It gives an occasion to search for and reconsider a meaning. It is related to the question "same or different" [31]. When a situation feels different, it activates a search for meaning.

Concern: A tentative plausible story (e.g., an opportunity, problem, perceived uncertainty, issue, or controversy) that the individual or group pay attention to.

Action: Through action, people produce parts of their environment and are "making" what is sensed [24]. People also enact what has been made sense of back into the world. In this study the main actions are identified, while acknowledging the challenge of simultaneously identifying both action and cognition [48].

Our analytical process follows the principle of "narrative analysis" proposed by Polkinghorne [50], incorporating analytical features from Boje's [45] causality analysis in an antenarrative perspective. Our narrative follows the characteristics of a narrated plot $[42,45,50]$, where beginning, middle, and ends of the story come into being. Such retrospective reconstruction often starts with the outcome as a starting point for how this event came about. In this case

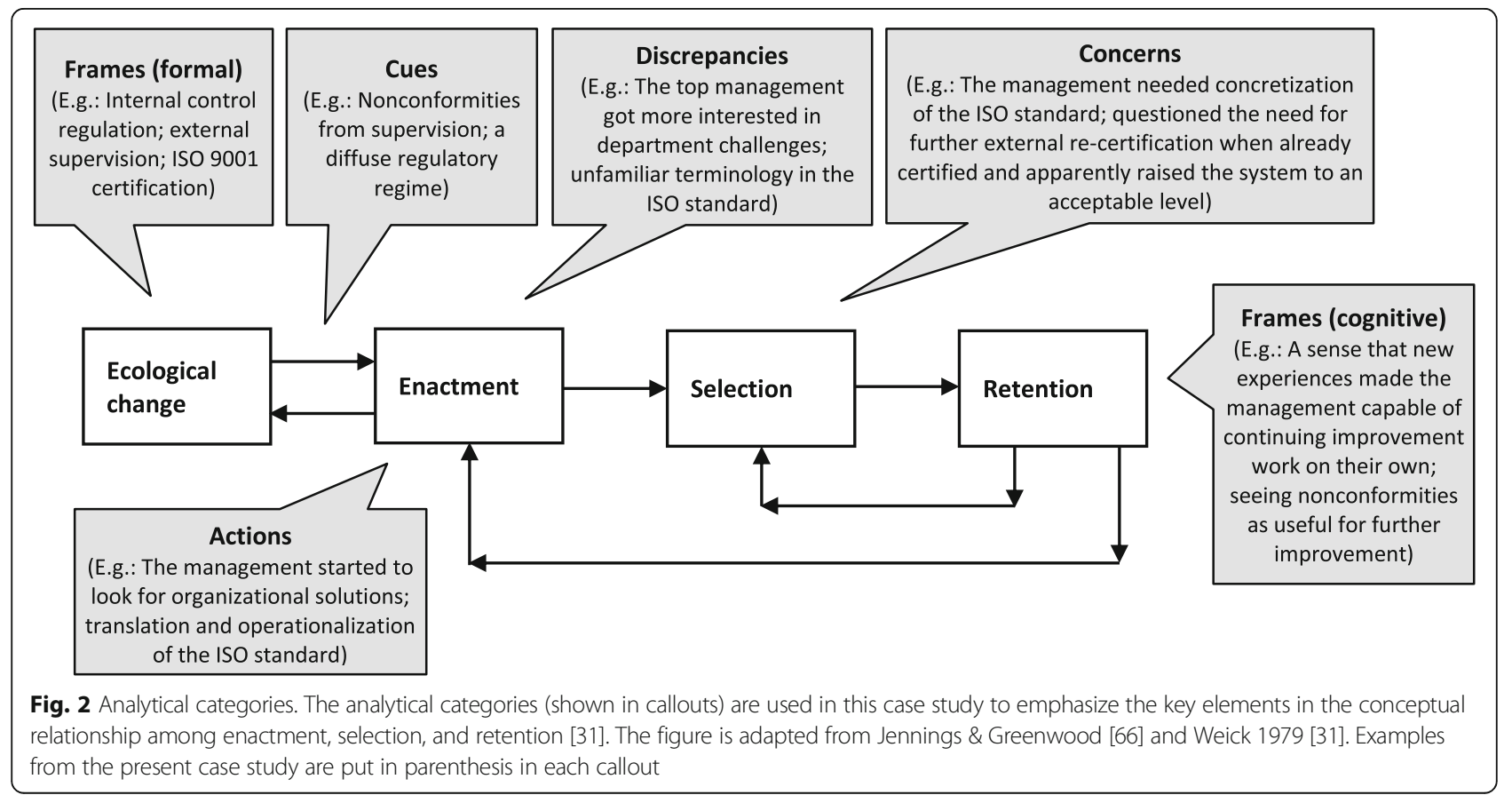


study the guiding outcome was the ED's adoption of ISO 9001 certification. Our first analytical step was to arrange the data elements chronologically and construct a baseline story. The baseline story was modified in an ongoing process along with a repeated reading of the interviews. In our next step we identified elements that are contributors to action and outcome [50]. Here the baseline story was categories into our analytical framework (Fig. 2). Our final analytical step was an ongoing construction (writing, categorizing, and rewriting) of the narrative into a temporally patterned whole [50]. We have visualized in brackets the categorization in the final narrative presented in this paper, to make the analytical process more transparent. To ensure trustworthiness, the narrative, with its analytical categories, was sent by e-mail to six of the informants, who confirmed the narrative. Only slight changes in the narrative were done after the informants' responses.

\section{Results}

\section{The story of change}

The following story is presented in two stages. The first outlines the initial establishment of the external project that initiated the pilot process in the ED. The second narrates the intra-organizational sensemaking that contributed to continuity and change in favor of ISO 9001 certification.

\section{Following up on unacceptable conditions in emergency departments}

In 2007 the Norwegian Board of Health Supervision (NBHS) carried out a countrywide supervision of 27 out of 54 hospital emergency departments in Norway, and concluded that in general, there was a lack of management responsibility for ensuring that daily tasks were planned, organized, carried out, and improved in accordance with legislative requirements [51]. The NBHS described the situation as unacceptable and required the management to take action.

As a direct follow-up of this report the Norwegian Accreditation $(\mathrm{NA})^{2}$ and one Regional Health Authority (RHA) initiated a collaborative project. Its objective was to set a standard that EDs could use to ensure and improve internal control and management systems, and for accreditation or certification purposes [52]. A sector committee ${ }^{3}$ including an administrative project organization, the regional project group (RPG), was established in the spring of 2008.

The sector committee was composed of representatives from all the RHA, NBHS, and other professional experts, and their work took place from August 2008 until March 2010. The new accreditation standard for EDs was supposed to concretize the generic requirements in the legal internal control regulation. The committee considered different management standards to build upon or implement, and decided on the ISO 9001:2008 Quality Management System - requirements standard, with its additional guidelines for use in health services [23]. The main reason was that the ISO 9001 was in compliance with the current Norwegian internal control regulation. Two ED was chosen as pilots for the project, in order to (1) identify core processes and risk areas to specify new requirements for EDs and (2) become ISO 9001 certified and meet the new requirements. One of the EDs ended the process before becoming certified, and the other, whose story is told in the next section, became certified in 2010 [53].

\section{The initial phase}

The ED had struggled for years with a heavy and challenging patient flow, and worked to improve the system without acceptable results [frame]. During this time there had been a change towards more attention to quality improvement and control, both through central, regional, and local initiatives. The RHA had become more explicit on requirements about, among others, waiting time for patients, patient safety, and prevention of infections [frame]. The ED was also in the middle of a rebuilding and merging process to take over the emergency functions from another hospital. The volume of patients was high, they were kept waiting, and there was not enough beds [concern].

The ED got two nonconformities from the countrywide supervision that required managerial follow-up. The first nonconformity pertained to the accumulation of patients that could lead to failure of treatment; the second was related to the examination conditions in the ED, which did not ensure adequate protection of confidentiality, patient integrity, and information exchange [cue]. The challenges in the ED were once again highlighted [cue] and the hospital top management became more involved in resolving these challenges [discrepancy]. The ED once again started to look for solutions and make efforts to improve patient flow [action].

Some months after the report from the NBHS, the hospital trusts in the RHA were asked to participate in the pilot project. The ED was then asked by their hospital CEO [cue]. The Head of Department had a quick consultation with middle managers in the ED, and the response was "Yes, let us jump on it" (Informant Y). They immediately decided to participate in the pilot [action]. Their expectation was to get the assistance to work systematically to resolve the challenges in the ED [concern].

The process in the ED started in autumn 2008. The first meeting was represented by people from the hospital who delivered services to the ED (e.g., physicians and the X-ray department) in addition to people from 
the regional project group. The intention was to anchor the project with concern to those departments that delivered services to the ED, and not just the ED in isolation [concern]. Especially, the integration of physicians was considered important [concern]. The head of department was the hospitals representative in the RPG and was highly involved in the development of the new requirement for EDs during spring 2009. She also became a key actor and a primer for the local pilot throughout the project.

During spring 2009, the ED established a local project group (LPG) led by the head of department and three middle managers [action]. At that time they did not know what to expect, other than they would be assessing and describing processes, identification of system vulnerabilities, and implementation of relevant actions in the ED [discrepancy]. In any case, they immediately threw themselves into the work, starting to describe processes and identify vulnerabilities [action]. After a while they were made aware of [cue] that the pilot project would involve the use of the ISO 9001 standard [discrepancy]. Then they realized their need for local assistance about developing quality management systems [concern]. A quality adviser from the Quality and Research Department integrated in the LPG [action]. The main work on ISO 9001 certification began in the summer of 2009.

\section{The standardization and certification phase: summer- autumn 2009}

The LPG worked enthusiastically and intensively, especially in July and August 2009. Most of the group members worked extra to complete the work [action]. The rest of the employees in the ED were less involved, limiting their participation to some ad hoc working groups, such as those to establish and revise procedures. Even though the LPG had agreed that the main intention for the ED was to review their management systems [frame], there seemed to be a clear awareness among the LPG members that the hard work on standardization consisted of taking steps towards certification [concern]. They had an opportunity for external help with improvement work, and this extra focus [cue] seemed to generate actions and a desire to demonstrate that they now were able to succeed [concern].

[I]t was a combination of several things. [...] When the crisis is big, it's even more important to get things done. It's a motivation in itself to do something-that was important. We were selected from the Regional Health Authority to accomplish this-that was an important element. [...] It turned out just like a competitive element, just like: 'This is something we can master'. Clearly, much was done before the certification body came in. We had been working very much; however, they did the last part in order to push us all the way to the end. (Informant Z)

None of the LPG members had experiences [frame] with ISO 9001 standardization and certification processes [discrepancy], except for one member of the quality department, who became an important "translator" [cue] of the ISO standard during the pilot project. The standard needed contextual adaptations to be legitimated in the ED [concern]. Terms like risk assessments, measuring, monitoring, and recording are obvious concepts and parts of an ISO quality management systems, but it was an unfamiliar terminology for the LPG [discrepancy]. The additional ED requirements developed during the project became important concretizations of the ISO 9001 standard and the internal control regulations. It generated a contextual translation [cue] of rather general requirements [discrepancy] and so ordinated a meaningful operationalization in the ED [action]. As "newcomers" [frame], the LPG needed concretization [concern].

The LPG referred favorably to the certification body. In the first phase of preparing the ED for the initial onsite document review, there was a large amount of email between the ED and the certification body. The hospital received much advice and help on how to improve the organization [cue]. The auditors were considered very detailed, sometimes almost too much [discrepancy], especially during document reviews and the certification audit. At the same time the auditors created confidence with their detailed knowledge and ability to identify salient points and ask questions about the documents and systems [cue]. They also transferred experiences from other organizations and brought expert knowledge on systems and change processes. The LPG experienced the certification process more as guidance than as control [discrepancy].

It was a turning point for the LPG when they received feedback from the certification body and gained experience from the standardization process itself [cue] that changed their understanding of systems that they had considered well-functioning: "things that we took for granted" (Informant Y), but were not good enough [discrepancy]. They started working differently with their systems [action] which generated an improved overview of their organization and tasks [cue], the number of procedures was reduced considerably [cue], and explicit objectives for improvement was created [cue]. The latter was a shift from describing objectives in general concerns, like "we should be better at..." to develop measurable objectives that could be monitored. The entire improvement and certification process [action] was considered as an important help [frame]. 
The initial countrywide supervision pinpointed the responsibility of other professions, especially physicians, to hold them accountable for the challenges in the ED [cue]. The emphasis on creating descriptions and visualization of core processes in the ED [action] made the department more visible and the process was considered a key to the shared understanding and commitment among leaders in other departments [cue]. The certification body drove this accountability concern further, and mutual contracts with "service" departments (including physicians) was a requirement for certification [cue]. "A milestone could be seen when agreements with other heads of departments became evident" (Informant X).

There were some worries among the employees in the ED about the perceived absence of management [cue], but the LPG did not enact any significant opposition either inside or outside the ED [cue]. The fact that the ED was a part of the pilot project and was supposed to [frame] organize for and deliver a service that was certifiable [discrepancy] was regarded as an important driver, not just for the LPG but also for other professions outside the ED that participated in working groups. It seemed that "no one" would contribute to the failure of a certification status, especially since it was decided at the top of the organization and as a direct follow-up of the external supervision [concern].

[T] he symbolic perspective of certification is just as prominent as the rational. I believe that, and that's my conclusion. Much of the things that we initiate are like that. Symbolic perspectives should not be underestimated (Informant Z).

After following up on the nonconformities that were given during the certification audit, the ED finally received its first ISO 9001 certificate in January 2010.

\section{The time after: winter 2010-summer 2012}

According to the managers and the LPG, the ISO certification process generated improvement of the management system; however, a direct impact on patient treatment was hard to demonstrate [frame]. ISO 9001 was considered as a managerial tool [frame]. When the revised management system was contrasted with the situation before certification, it illustrated both positive practical implications and improved daily organizing of the ED [frame]. The ED management started talking differently about quality improvement, and used terms and explanations that had originated from the standardization and certification process [action]. They were proud of their achievement and gladly shared their material and experiences. The ISO standard and the additional requirements for EDs were not considered the optimum way of organizing, but it was treated as one way, among many others, that generated system improvement [frame]:

[T] he fact that we are ISO-certified-as I say: We have put some things in place; it is easier to find, easier to breathe, you don't need to doubt, you don't have to look; it is helping to create those secure frames. So that those who work within these frames are given the opportunity to flourish in the face of the patient. (Informant W)

Even though the LPG considered the certification process to imply system improvement [frame], they did not expect that the employees would perceive quality improvements, or associate system changes with the ISO certification [concern], since the certification process did not really affect the daily operations and patient treatment. At least two other quality improvement initiatives (triage and nurses' continuing education) were initiated in parallel with the certification process, and these were considered to have more positive association with improved treatment quality compared to the ISO certification [cue].

The ED underwent two yearly surveillance audits ${ }^{4}$ conducted by the certification body after the initial certification audit. These external assessments were considered important for sustainability of quality improvement [cue], even though the management understood that quality improvement should be part of everyday practice [discrepancy]. Whether these audits needed to be performed by a third-party certification body was not considered of major importance, and neither was the importance of the certificate in itself [Frame].

The ED management started to question the need for further use of an external certification body [concern]. These concerns were based on (1) negative experiences from the latest surveillance audit, where a new team from the certification body conducted the audit [discrepancy], (2) the costs and resources spent [frame], and (3) having brought their quality management system to an acceptable level. The ED management had generated knowledge that enabled the ED to perform ongoing system improvements on its own [frame]. However, some sort of external audit was considered necessary [concern]. Internal audits performed by the quality department in the hospital was in theory considered equal with external audits, but in practice the external audits (e.g., by a certification body, NBHS, or the RHA) had stronger impact and triggered more managerial action than internal audits [discrepancy]. Managers from the LPG changed their perspective on audits, from seeing them as a way of controlling organizations to something useful for sustainable improvement [frame]. They started 
asking for internal audits and acknowledged the possibility of letting someone outside the department assess their systems and give feedback [action]. Nonconformities were used as means for further improvement [frame].

$[F]$ or the last couple of years we have requested audits, when there are things we are questioning. [...] It's not so frightening anymore, and we see that it's very useful for us. That I think is a result of the process. We are not so afraid of getting nonconformities, and see that these [nonconformities] are things that we can work on. (Informant V)

\section{Discussion}

As a result of the countrywide supervision, the Norwegian EDs were turned inside out in ways that made it obvious to ask whether it was safe to be a patient there. The turbulence did not lead to additional formal national inquiries or major policy changes that we have seen from turbulence or health care crises in other countries [54], but it was thoughtless disruption or turbulence that was a powerful occasion for organizational change [26]. The story of the adoption of an unfamiliar set of organizational requirements (ISO 9001), that had a quite circumstantial influence on the local ED management, fits at first glance into the picture of sensemaking, where action and interpretation rather than evaluation on choice were present in the first face of the adoption process. A quick decision to become part of the pilot project was taken in the face of longstanding challenges in the ED related to patient flow and management systems. These challenges had become a frame of reference for the management, and different initiatives to resolve them had become discrepancies between what had been expected and the reality. It was not a surprise or a shock that prompted sensemaking, but ongoing discrepancies as circumstances great enough to expect people to ask for what is going on, and what should they do next. This situation challenged the management's social and shared identity $[24,26,31]$, as they were responsible for the quality and safe running of the ED. Such an internal turbulent environment can in itself be treated as a trigger for managers' engagement in sensemaking towards that specific challenge or threat [55]. The importance here is how the external environment triggered sensemaking processes that initiated the adoption, continuation, and change in favor of ISO 9001 certification and additional standards. Four external triggers are identified. The first two external triggers (nonconformities and regional certification project participation) were situational-specific and present initially in the process. The last two triggers are institutional in nature [25], derived from perceived ambiguities in relative stable institutional structures (the current internal control regulation and the ISO 9001 certification). These ambiguities triggered sensemaking processes around continuity and change (the organizing processes) towards internal control systems and certification.

\section{Situational triggers}

The first trigger relates to the nonconformities from the countrywide ED supervision. For the ED management, the nonconformities did not cause disruption, but rather verification of known challenges. What they now perceived as different from earlier (a discrepancy), was the increased focus upon these known challenges and turbulence from the hospital's top management. Treated institutionally, such an increased focus can be explained by demands to follow up on nonconformities through institutional coercion $[56,57]$ or regulatory enforcement [58]. But in the sense that these onsite supervisions are ad hoc initiatives, most often with years in between, they also have the potential to cause careless disruption or surprises for organizations that can offer strong occasions for sensemaking. Basically, it can be an interruption produced by new and unexpected circumstances [24]. This seems to be true in this case study, where the received nonconformities made known challenges "visible" [59] for other parts of the organization and especially the top management, and so triggered further actions for control and accountability.

The second trigger relates to the way in which external possibilities for assistance and support led to "quick" action and interpretation. The ED management's uncertainty about proper solutions threatened their social identity. The external possibilities for support prompted almost immediate action. Organizational uncertainty can be seen as a form of ignorance or an inability to extrapolate current actions and therefore foresee future consequences [24]. Such occasions lead people to construct processes of sensemaking to reduce that ignorance. Plausibility and belief about current action, rather than accuracy about the future, are salient in such sensemaking processes. Early available sources and information that gave some sort of plausible directions for the ED, replaced uncertainty about the future, with more certainty about the present, and as such made it possible to continue. The shared belief among the ED management prompt action, rather than change resistance, that often are seen in organizational change when identity is challenged due to identity replacement, updating, or transformation $[26,55]$.

\section{Institutional triggers}

The third trigger relates to institutional structures in the current internal control regulation. Adoption of internal 
control system has shown to be a challenging task in health care [60], and the ED did not have a system that was clearly built up around a fulfillment of these regulatory requirements. Finding solutions to operationalize these requirements was inherent in the pilot project. The LPG's work on concretizing the requirements and developing additional requirements for EDs set in motion important sensemaking processes about the internal control regulation. The internal control system is founded in a functional legislation $[34,61]$ with a wide scope and possibilities for organizations to choose among a variety of tools for quality and safety work [62]. It is a form of soft regulation that can be (too) diffuse and therefore trigger organizations' search for control $[28,30]$. It becomes a question of transparency and accountability [59], not just in the eyes of external actors, but for the organizations themselves. Because making things transparent is not just about documenting and open the "curtains" for direct insight, it is also about adopting new technologies that make organizational performance visible [59]. The process of concretizing the requirements in the internal control regulation that the LPG performed was such a necessary visualization that gave meaning to their own system and processes [32]. When analyzed from the perspective of Weber and Glynn's [25] institutional trigger mechanism, we see that the stable institutional structure inherent in the regulatory system became ambiguous for the LPG and trigged further sensemaking that made organizing possible. These findings support other research arguing that a lack of competence on developing internal control systems makes it difficult to adapt to the internal control regulation in Norway [60].

The fourth trigger relates to the institution of ISO 9001 certification. The present case study shows that the ISO 9001 standard consisted of general and unfamiliar concepts and systems that triggered the LPG to find ways to translate and contextualize these ambiguities, in their efforts to make sense of the standard. Seeing the ISO standard as a trigger relates to the same institutional triggering mechanism as for the third trigger. What is different about the institution of ISO 9001 certification is that it involves auditing process performed by external auditors, and therefore integrates direct feedback mechanisms that are interlinked with sensegiving perspectives [31, 63] or mechanisms on how institutions edit sensemaking [25]. Auditors control, negotiate, and guide during their interactions with the organizations, and those tasks give auditors room for different interpretations and conducts of their same auditing role. Concerns about interaction are important, because research on accreditation shows that when health professionals are given the opportunity to participate in assessment contexts that are collaborative and supportive, it can self-reinforce a collaborative quality and safety culture [64]. These considerations on the auditor-auditee encounter may also underpin our present findings where there was a perceived discrepancy between the conduct of the first audit team (performing both the initial certification audit and the first surveillance audit the first year) and the conduct of the last surveillance audit team the second year. The first team was perceived by the LPG to have real impact upon the standardization and improvement work in the ED. The conduct of the second team was so different that it made the ED management question the reliability of the certification process and the meaning of renewing their certificate.

A recent study [65] on stakeholder perspectives identified four factors that seemed important to increase the likelihood of a successful implementation of accreditation: (1) the program is collaborative and valid and uses relevant standards; (2) that accreditation is favorably received by health professionals; (3) that healthcare organizations are capable of embracing accreditation; (4) and that accreditation is appropriately aligned with other regulatory initiatives and supported by incentives. These findings highlight external regulatory structures and intra-organizational factors that seem to be in line with findings on triggers and organizing perspectives related to certification in our study.

\section{Limitations}

This single-case study is limited to meaning making processes within a single emergency department in a single hospital in Norway. The small sample is a clear limitation of generalization from this study.

\section{Conclusions}

Certification and accreditation are widely used for quality and safety in health care but also questioned in respect to their assumed effects. This is a challenge for policymakers since these regimes can have a circumstantial impact upon different parts of the organization. The present case study shows that the adoption of the ISO 9001 certification in an emergency department was not led by a comprehensive decision-making process. It shows that an exogenous disruption visualized longstanding organizational challenges that threatened the managements shared identity. Again a search for meaning became prominent. The occasional possibility for help through an external standardization and certification project was a plausible solution that led to immediate action, and reduced uncertainty. Further, the case study shows that the relative stable institutional requirements that are inherent in the internal control regulation and the certification standard were unfamiliar and ambiguous and therefore triggered local sensemaking processes for a contextualization of these regulations 
and standards, which made the continuation and change possible. It also led to the acknowledgment of external assessments or audits in general as useful for improvement work.

When considering implications for further theory development, we see that the institutional trigger mechanism in Weber and Glyns' [25] framework contributes to explaining the occasion for sensemaking. There is a need for more research that can refine this institutional mechanism (in addition to institutional constraints) and inform explanations of why some regulatory institutions give rise to (trigger) adoption of different modern management tools (e.g., certification or accreditation). These considerations are important, because when organizations adopt new management tools, they seldom abandon others. This can lead to even more complex health care.

\section{Endnotes}

${ }^{1}$ Governance in this perspective refers more to the neoliberal approaches inspired by rational choice theories and governance as networks within the institutional tradition, than to a decentered theory of governance underpinned by postfoundational philosophy and democratic stands [67].

${ }^{2}$ Norwegian Accreditation (NA) is the Norwegian body for accreditation of laboratories and sampling organizations, certification bodies, inspection bodies, and environmental verifiers. NA represents Norway on three European and international bodies-the European cooperation for Accreditation, the International Laboratory Accreditation Cooperation and the International Accreditation Forum. NA is also the Norwegian monitoring body for Good Laboratory Practice (GLP) inspections, according to OECD's GLP principles (http://www.akkreditert.no/en/om-oss/, accessed 12. February 2014).

${ }^{3}$ Norwegian Accreditation establishes different sector committees, often broadly represented, when the aim is to establish a new standard on a new domain or sector.

${ }^{4}$ Surveillance audit is a yearly onsite audit so that the certification body can maintain confidence that the certified management system continues to fulfill requirements between (re-)certification and re-certification [21].

\section{Abbreviations}

ED: Emergency department; ISO: International Organization for

Standardization; LPG: Local project group; NBHS: Norwegian Board of Health Supervision; RHA: Regional Health Authorities; RPG: Regional project group

\section{Acknowledgements}

The authors would like to thank the hospital for the access to the field and also thanks so much to all informants for taking part in the study and for giving feedback on the narratives to the authors. We would like to thank the Ministry of Education and Research for the funding of the PhD project.

\section{Funding}

This article is part of a PhD project funded by the Ministry of Education and Research in Norway.

\section{Availability of data and materials}

The data generated and analyzed during this study are not publicly available due to concerns about confidentiality regarding a small sample size and the sensitive nature of the interviews. Instead, quotations and analytical categories are included in the text. We are happy to discuss the findings or the analysis if any questions should arise.

\section{Authors' contributions}

DTSJ was responsible for the conception and design of the study and undertook acquisition of data as well as analysis and interpretation of data. SW was consulted during the analysis, and interpretation process. DTSJ led the drafting of the manuscript. DTSJ and SW were both involved in critically revising the manuscript for important intellectual content and both read and approved the final manuscript.

\section{Ethics approval and consent to participate}

The research was performed with the ethical approval of the Norwegian Social Science Data Services (December 16, 2011, Ref. 27543). A clearance for staff interviews was obtained from the hospital prior to data collection. Informants first got a written invitation to participate at its inception and then a written and oral invitation prior to the commencement of recording. The invitation explained that the interview was part of a research project, that the results would be used anonymously for analysis and publication, and that participation was voluntary and could be terminated at any time. All informants provided oral consent.

\section{Consent for publication}

Our manuscript does not contain any individually identifiable person's data. All informants have got the opportunity to read and respond to a late draft of the manuscript, including quotes, before submission.

\section{Competing interests}

The authors declare that they have no competing interests.

\section{Publisher's Note}

Springer Nature remains neutral with regard to jurisdictional claims in published maps and institutional affiliations.

\section{Author details}

${ }^{1}$ Department of Media, Culture and Social Sciences, University of Stavanger, 4036 Stavanger, Norway. ${ }^{2}$ Department of Health and Nursing Science, University of Agder, 4604 Kristiansand, Norway. ${ }^{3}$ Department of Health Studies, University of Stavanger, 4036 Stavanger, Norway.

Received: 16 May 2017 Accepted: 4 July 2017

Published online: 19 July 2017

\section{References}

1. Storting: Case 2: Recommendation from the healthcare committee about the representative proposals from members of parliament Erna Solberg, Inge Lønning and Sonja Irene Sjøli about better quality in hospital [In Norwegian: Innstilling fra helse- og omsorgskomiteen om representantforslag fra stortingsrepresentantene Erna Solberg, Inge Lønning og Sonja Irene Sjøli om bedre kvalitet i sykehus] (Innst. S. nr. 204 (20082009), jf. Dokument nr. 8:29 (2008-2009)). Minute from meeting Thursday 14. May 2009. 10.00 A.M. 2009: 3004-3009.

2. Norwegian Ministry of Health and Care Services. Meld.St. 10 (2012-2013) Report to the storting (white paper). High Quality - Safe Services. Quality and Patient safety in the Health and Care Services. 2012.

3. Norwegian Ministry of Health and Care Services. Meld.St. 11 (2015-2016) Report to the storting (white paper). Nasjonal helse- og sykehusplan (2016-2019). 2015

4. Greenfield D, Braithwaite J. Developing the evidence base for accreditation of healthcare organisations: a call for transparency and innovation. Qual Safety Health Care. 2009:18(3):162-3.

5. Brubakk K, Vist GE, Bukholm G, Barach P, Tjomsland O. A systematic review of hospital accreditation: the challenges of measuring complex intervention effects. BMC Health Serv Res. 2015;15(1):280. 
6. Grepperud S. Is the hospital decision to seek accreditation an effective one? Int J Health Plann Manag. 2015;30(1):E56-68.

7. Flodgren G, Gonçalves-Bradley DC, Pomey M-P. External inspection of compliance with standards for improved healthcare outcomes. Cochrane Database System Rev. 2016;12:CD008992.

8. Haute Autorité de Santé: Literature review on the impact of hospital accreditation. In. Paris: MATRIX Knowledge group; 2010.

9. Greenfield D, Braithwaite J. Health sector accreditation research: a systematic review. Int J Qual Health Care. 2008;20(3):172-83.

10. Hinchcliff R, Greenfield D, Moldovan M, Westbrook Jl, Pawsey M, Mumford $\mathrm{V}$, Braithwaite J. Narrative synthesis of health service accreditation literature. BMJ Quality Safety. 2012;21(12):979-91.

11. Sunol R, Vallejo P, Thompson A, Lombarts MJMH, Shaw CD, Klazinga N. Impact of quality strategies on hospital outputs. Qual Safety Health Care. 2009;18 Suppl 1:162-8.

12. Shaw C, Groene O, Mora N, Sunol R. Accreditation and ISO certification: do they explain differences in quality management in European hospitals? Int J Qual Health Care. 2010;22(6):445-51.

13. Shaw CD, Groene $O$, Botje D, Sunol R, Kutryba B, Klazinga N, Bruneau C, Hammer A, Wang A, Arah OA, et al. The effect of certification and accreditation on quality management in 4 clinical services in 73 European hospitals. Int J Qual Health Care. 2014;26 suppl 1:100-7.

14. Falstie-Jensen AM, Larsson H, Hollnagel E, Nørgaard M, Svendsen MLO, Johnsen SP. Compliance with hospital accreditation and patient mortality: a Danish nationwide population-based study. Int J Qual Health Care. 2015;27(3):165-74

15. Devkaran $\mathrm{S}, \mathrm{O}$ 'Farrell PN. The impact of hospital accreditation on quality measures: an interrupted time series analysis. BMC Health Serv Res. 2015;15(1):137.

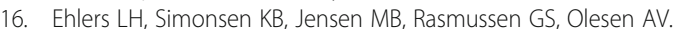
Unannounced versus announced hospital surveys: a nationwide clusterrandomized controlled trial. Int J Qual Health Care. 2017;1:6.

17. Shaw CD, Braithwaite J, Moldovan M, Nicklin W, Grgic I, Fortune T, Whittaker S. Profiling health-care accreditation organizations: an international survey. Int J Qual Health Care. 2013;25(3):222-31.

18. Bromley P, Powell WW. From smoke and mirrors to walking the talk: decoupling in the contemporary world. Acad Manag Ann. 2012;6(1): 483-530.

19. Shaw C. External assessment of health care. BMJ. 2001;322(7290):851-4.

20. Bohigas $L$, Heaton $C$. Methods for external evaluation of health care institutions. Int J Qual Health Care. 2000;12(3):231-8.

21. ISO. Conformity assessment-requirements for bodies providing audits and certification of management systems (ISO/IEC 17021:2011). 2011.

22. ISO. Quality management systems- requirements (ISO 9001:2008). 2008.

23. European Committee for Standardization. CEN/TS 15224:2005 - Quality Management in health services, Guidelines for the use of NS-EN ISO 9001: 2000. 2005.

24. Weick KE. Sensemaking in organizations. Thousand Oaks: Sage; 1995.

25. Weber K, Glynn MA. Making sense with institutions: context, thought and action in Karl Weick's theory. Organ Stud. 2006;27(11):1639-60.

26. Maitlis S, Sonenshein S. Sensemaking in crisis and change: inspiration and insights from Weick (1988). J Manag Stud. 2010;47(3):551-80.

27. Powell WW, Colyvas JA. Microfoundations of institutional theory. In: Greenwood R, Oliver C, Suddaby R, Sahlin K, editors. The Sage Handbook of Organizational Institutionalism. Volume 1. London: SAGE Publication; 2008.

28. Djelic M-L, Sahlin-Andersson K. Introduction: a world of governance: the rise of transnational regulation. In: Djelic M-L, Sahlin-Andersson K, editors. Transnational governance: institutional dynamics of regulation. Cambridge: Cambridge University Press; 2006. p. 1-28.

29. Black J. Constructing and contesting legitimacy and accountability in polycentric regulatory regimes. Reg Govern. 2008;2(2):137-64.

30. Sahlin K, Wedlin L. Circulating ideas: imitation, translation and editing. In: Greenwood R, Oliver C, Suddaby R, Sahlin K, editors. The SAGE Handbook of Organizational Institutionalism. London: Sage; 2008. p. 218-42.

31. Weick KE, Sutcliffe KM, Obstfeld D. Organizing and the process of sensemaking. Organ Sci. 2005;16(4):409-21.

32. Weick KE. Quality improvement. A sensemaking perspective. In: Cole RE, Scott WR, editors. The quality movement \& organization theory. Thousand Oaks: Sage; 2000. p. 155-72.

33. Mills JH. Making sense of organizational change. New York: Routledge; 2003.

34. Coglianese C, Mendelson E. Meta-regulation and self-regulation. In: Baldwin $\mathrm{R}$, Cave $\mathrm{M}$, Lodge $\mathrm{M}$, editors. The Oxford handbook of regulation. Oxford: Oxford University Press; 2010. p. 146-68.
35. Regulations of 20. December 2002 realting to internal control in the socia and health services [In Norwegian: FOR 2002-12-20 nr 1731: Forskrift om internkontroll i sosial- og helsetjenesten]; 2002

36. Schaefer C, Wiig S. Strategy and practise of external inspection in healthcare services-a Norwegian comparative case study. Safety in Health. 2017;3(1):3.

37. Eastern Norway Regional Health Authorities: Annual report from the Eastern Norway RHA to the Ministry of Health and Care Services [In Norwegian: Årlig melding fra Helse Øst RHF til Helse- og omsorgsdepartementet]. Hamar; 2005.

38. Arntzen E, Mikkelsen B. Internkontroll, sertifisering og akkreditering. Tisdsskrift Nor Lægeforen. 2005;6(125):767-9.

39. Yin RK. Case study research: design and methods. 5th ed. Los Angeles: Sage; 2014.

40. Rhodes C, Brown AD. Narrative, organizations and research. Int J Manag Rev. 2005;7(3):167-88.

41. Langley A. Strategies for theorising from process data. Acad Manag Rev. 1999;24(4):691-710.

42. Czarniawska B. Narratives in social science research. London: Sage Publications; 2004

43. Brown AD, Stacey $P$, Nandhakumar J. Making sense of sensemaking narratives. Human Relations. 2008;61(8):1035-62.

44. Currie G, Brown AD. A narratological approach to understanding processes of organizing in a UK hospital. Human Relations. 2003;56(5):563-86.

45. Boje DM. Narrative methods for organizational and communication research. London: Sage; 2001.

46. Brown AD, Gabriel Y, Gherardi S. Storytelling and change: an unfolding story. Organization. 2009;16(3):323-33.

47. Gubrium JF, Holstein JA, Marvasti AB, McKinney KD. The SAGE handbook of interview research: the complexity of the craft. 2nd ed. Thousand Oaks: Sage; 2012.

48. Steyer V, Laroche H, Jonczyk C. The Crisis that did not Happen: a study of Multi-Level Sensemaking. Paper presented at the Second International Symposium on Process Organization Studies. Rhodes: International Symposium on Process Organization Studies; 2010.

49. Weick KE. Making sense of the organization. Oxford: Blackwell; 2001

50. Polkinghorne DE: narrative configuration in qualitative analysis. In: Life History and Narrative. edn. Edited by Hatch JA, Wisniewski R: Taylor and Francis; 1995.

51. Norwegian board of Health Supervision. "While we are waiting...."-do patients receive adequate treatment in accident and emergency units? Summary of countrywide supervision in 2007 of accident and emergency units in specialized health services - are services of adequate quality and do they meet legislative requirements? In: Report from the Norwegian Board of Health Supervision 2/2008. 2008.

52. South-East Norway Regional Health Authority, Norwegian Accreditation. Project Proposel - Accreditation in Emergency Departments "... for good and equal health services" [In Norwegian: Prosjektplan - Akkreditering i akuttmottak." ...for gode og likeverdige helsetjenester."]. Oslo; 2008.

53. Norwegian Accreditation. Report from the Norwegian Accreditation Sector committee P-14 Emergency Departments [In Norwegian: Rapport fra Norsk Akkrediterings sektorkomite P-14 akuttmottak]. 2011.

54. Hindle D, Braithwaite J, Travaglia J, ledema R. Patient Safety: a comparative analysis of eight Inquiries in six countries. Sydney: Centre for Clinical Governance Research, Faculty of Medicine, University of New South Wales; 2006.

55. Maitlis S, ChristiansoN M. Sensemaking in Organizations: Taking stock and moving forward. Acad Manag Ann. 2014;8(1):57-125.

56. DiMaggio PJ, Powell WW. The iron cage revisited: institutional isomorphism and collective rationality in organizational fields. Am Sociol Rev. 1983;48(2): 147-60.

57. Scott WR. Institutions and organizations: ideas and interests. Thousand Oaks: Sage Publications; 2008.

58. Gunningham N. Enforcement and compliance strategies. In: Baldwin R, Cave M, Lodge M, editors. The Oxford handbook of regulation. Oxford: Oxford University Press; 2010. p. 120-45

59. Blomgren M, Sahlin K. Quests for transparency: signs of a new institutional era in the health care field. In: Christensen T, Lægreid P, editors. Transcending new public management: the transformation of public sector reforms. Aldershot: Ashgate; 2007. p. 155-77.

60. Wiig S, Storm M, Aase K, Gjestsen M, Solheim M, Harthug S, Robert G, Fulop N. Investigating the use of patient involvement and patient experience in quality improvement in Norway: rhetoric or reality? BMC Health Serv Res. 2013;13:206. 
61. Ayres I, Braithwaite J. Responsive regulation: transcending the deregulation debate. New York: Oxford University Press; 1992.

62. Gilad S. It runs in the family: meta-regulation and its siblings. Reg Govern. 2010;4(4):485-506

63. Maitlis S, Lawrence TB. Triggers and enablers of sensegiving in organizations. Acad Manag J. 2007:50(1):57-84.

64. Greenfield D, Pawsey M, Braithwaite J. What motivates professionals to engage in the accreditation of healthcare organizations? Int J Qual Health Care. 2011;23(1):8-14.

65. Hinchcliff R, Greenfield D, Westbrook Jl, Pawsey M, Mumford V, Braithwaite J. Stakeholder perspectives on implementing accreditation programs: a qualitative study of enabling factors. BMC Health Serv Res. 2013;13(1):1-9.

66. Jennings PD, Greenwood R. $6 \mathrm{~b}$ constructing the iron cage: institutional theory and enactment. In: Westwood Rl, Clegg S, editors. Debating organization: point-counterpoint in organization studies. Malden: Blackwell Publishing; 2003. p. 195-207.

67. Bevir M. A theory of governance. London: University of California Press; 2013.

Submit your next manuscript to BioMed Central and we will help you at every step:

- We accept pre-submission inquiries

- Our selector tool helps you to find the most relevant journal

- We provide round the clock customer support

- Convenient online submission

- Thorough peer review

- Inclusion in PubMed and all major indexing services

- Maximum visibility for your research

Submit your manuscript at www.biomedcentral.com/submit
C) Biomed Central 